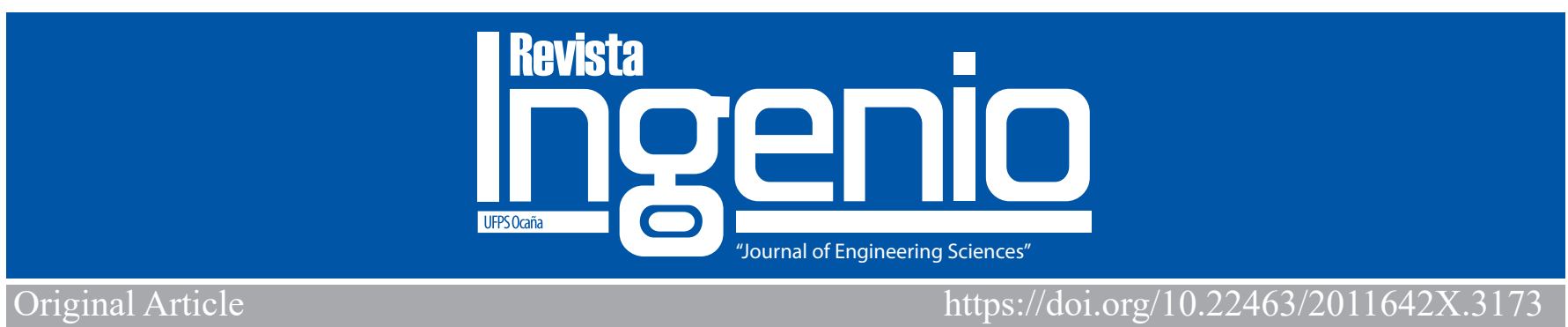

\title{
Review of entrepreneurship in the COVID-19 era
}

\author{
Revisión del emprendimiento en la era COVID-19
}

\section{Ph.D José Marcos Bustos-Aguayo ${ }^{1}$, Ph.D Margarita Juárez-Nájera², Ph.D Cruz García-Lirios ${ }^{3}$}

' Departamento de Psicología, Universidad Nacional Autónoma de México, México, Orcid: https://orcid.org/0000-0003-3423-596X, E-mail: marcos.bustos@unam.mx

${ }^{2}$ Departamento de Energía, Universidad Autónoma Metropolitana, México, Orcid: https://orcid.org/0000-0002-7447-8213, E-mail: mjn@azc.uam.mx

${ }_{3}^{3}$ Departamento de Trabajo Social, Universidad Autónoma del Estado de México, México, Orcid: http://orcid.org/0000-0002-9364-6796 Email: cgarciali@uaemex.mx

How to cite: J. M Bustos-Aguayo, M Juárez-Nájarea \& C. García-Lirios, "Review of enterpreneurship in the COVID-19 era", Revista Ingenio, vol. 19 (1), pp.60-66, 2021.

\section{ABSTRACT}

Keywords:

Covid-19,

Entrepreneurship, Model,

Repository, Social Work
In the Covid-19 era, the policies of confinement and distancing of people open up areas of opportunity that the present study set out to analyze. A documentary, systematic and retrospective work was carried out with a selection of sources indexed to international repositories, considering the period of the pandemic from December 2019 to November 2021. A structural equation model was established in which the prevalence of five dimensions reported in the literature: opportunism, efficacy, environmentalism, governance and resilience. In relation to anti-Covid-19 policies, axes of review and discussion are recommended to contribute to the public agenda.

\section{RESUMEN}

Palabras claves:

Covid-19,

Emprendimiento, Modelo,

Repositorio, Trabajo

Social
En la era Covid-19, las políticas de confinamiento y distanciamiento de personas abren áreas de oportunidad que el presente estudio se propuso analizar. Se realizó un trabajo documental, sistemático y retrospectivo con una selección de fuentes indexadas a repositorios internacionales, considerando el periodo de la pandemia de diciembre de 2019 a noviembre de 2021. Se estableció un modelo de ecuaciones estructurales en el que se observó la prevalencia de cinco dimensiones reportadas en la literatura: oportunismo, eficacia, ambientalismo, gobernanza y resiliencia. En relación con las políticas anti Covid-19 se recomiendan ejes de revisión y discusión para contribuir a la agenda pública.

\section{Introduction}

In the context of the pandemic, anti-COVID-19 policies are distinguished by bringing together various sectors and social strata around risk prevention [1]. The infections, diseases and deaths associated with the SARS CoV-2 coronavirus are abated from mitigation and containment policies, as well as distancing strategies, confinement and immunization programs[2]. In this scenario, the State, in terms of financing, has oriented the undertaking towards the most vulnerable sectors, although it recommends reactivation after the vaccination scheme.

Entrepreneurship is defined as the optimization of resources and process innovation[3]. The optimization of resources suggests the management of opportunities in risk situations such as the pandemic[4]. The state of exception is declared due to the scarcity of resources, the growing unhealthiness and the shortage of medicines because the demand exceeds the supply[5]. In this perspective, the State orchestrates the optimization of resources by disseminating microfinance for micro and small companies because $90 \%$ of jobs are generated by this sector[6]. The optimization of resources supposes the redistribution of supports.

However, the redistribution of incentives to micro and small companies assumes that the State knows the relationship between local or sector supply and demand[7]. Since the information related to preferences, choices and consumptions is updated and assumes a non-linear dynamic, the optimization is limited[8]. Consequently, the government adopts a process innovation strategy to fill the data gap to guide the venture[9]. Microfinance oriented towards new forms of commerce is included in process innovation[10]. The State generates fiscal and monetary incentives to reactivate local commerce based on innovative advantages[11]. This is the case of communities organized in cooperatives and associated with municipal development programs.

Even though the governors and the governed establish an exceptional synergy in the face of a risk scenario, the 
structure of this undertaking has not been disclosed[12]. The literature warns that optimization and innovation are related but indicates the dimensions that link them[13]. The objective of this work was to analyze the structure of entrepreneurship reported in the literature during the pandemic.

Are there significant differences between the dimensions reported in the literature with respect to the observations made in the present work?

The premise that guides this work suggests the dimensions of entrepreneurship derive from contingent scenarios[14]. It means then that the optimization of resources and the innovation of processes are complementary[15]. Furthermore, the features of both dimensions imply a link between State strategies and local initiatives. Opportunities, expected results, environmental requirements, local resilience and governance underlie this scenario.

\section{Theory of social entrepreneurship}

The theoretical and conceptual frameworks that explain entrepreneurship assume its emergence in risky contexts[16]. In the case of the pandemic, entrepreneurship theory considers opportunism to be an initial reaction of the actors[17]. The state and workers take advantage of the opportunities that underlie the scarcity of resources, but they also generate opportunities from innovative proposals[18]. The difference between optimization and innovation is explained from the theory of entrepreneurship as an anticipated efficiency[19]. The policies and strategies that guide optimization depend on expected results, but if they promote innovations, they guide collaboration towards competition[20]. The State encourages entrepreneurship from the redistribution of financing but generates trust by allowing innovation.

Anticipated effectiveness is built from trust between the arts involved[21]. The results are achieved when the interested parties establish alliances based on the image of effectiveness or the prestige of the achievements[22]. Optimization assumes a relationship of mistrust because a result is expected, while innovation is synonymous with confidence because no goals are set and only increasing benefits are expected[23]. The State that trusts entrepreneurs knows that their investment will return and activate a climate of support and collaboration[24]. Entrepreneurs who trust the government do not know the amount of support and delivery dates, but they are sure that the State will support them.

Trust breeds anticipated effectiveness. By adding environmentalism to opportunism and trust, it enhances entrepreneurship[25].The Sustainable Development Goals (SDG) and the Summit of the Parties (COP-26) are guidelines and instruments of trust between the governors and the governed[26]. Entrepreneurship emerges when the government and workers follow the SDGs, but optimization and innovation underlie when governments commit to protecting workers' proposals at summits[27]. If trust prevails between the rulers and the ruled, then the venture acquires a symbolic efficacy.

Resilience is more than a response to risk events such as pandemic, floods, droughts, fires, frosts or earthquakes[28]. Before establishing a relationship of trust between the State and entrepreneurs, resilience brings together negative and positive factors[29]. After the trust between the parties, resilience is seen as an initiative or anticipation of risk events[30]. In this way, resilience is indicative of entrepreneurship because it is specified in actions that give value to the rulers and the governed.

Governance underlies governance in a scenario of resilience, opportunism, efficacy, and environmentalism among interested peers[31]. The system in which the State and entrepreneurs open the discussion around the amount of support, consensus regarding promotions and coresponsibilities in the mid-term is known as governance[32]. Once the parties involved reach an observable resilience for their initiatives and agreements, they can co-govern themselves[33]. That is, state management and social self-management of resilience achieve a socio-state comanagement or governance. Entrepreneurship acquires an inexorable social political dimension for the parties involved[34]. This is the case of Scandinavian localities where the government is a facilitator of co-management and does not intervene without prior negotiation with the communities.

\section{Studies of social entrepreneurship}

Research showing a significant relationship between resource optimization and process innovation in the face of the pandemic maintains: 1) opportunism is an effect of the health and economic crisis; 2) resource optimizations emerge from State intervention through mitigation and distancing policies; 3) process innovations are inherent to distancing and confinement because they imply a confidence of the entrepreneurs in the economic rescue of the government; 4) the parties involved achieve resilience once they have agreed on partnership and collaboration mechanisms; 5) governance is appreciated when entrepreneurs and governments follow a co-management strategy.

Studies have proposed instruments to measure relationships between categories, variables, and indicators[35].The digital entrepreneurship inventory measures the relationship between digital promotion policies and proposals for intersectoral collaboration through 
data mining[36]. The social entrepreneurship scale is responsible for weighing the relationships of trust between the parties involved[37]. The social support questionnaire establishes the relationships between entrepreneurs and family or cooperative investors[38]. Each instrument reports high reliability indices that are interpreted as consistent relationships between the main category with respect to the variables and indicators of local entrepreneurship.

The relationships between categories, variables and indicators are reported as significant[39]. These are the cases of entrepreneurship and opportunism as a distinctive feature of risk scenarios[40]. Furthermore, opportunism is associated with the optimization of resources in uncertain contexts[41]. Instead, process innovation is linked to creativity as a response to situational crises[42]. It is the effectiveness that has only been reported as an effect of confidence[43]. Resilience is a cause and effect of entrepreneurship[44].Governance is concomitant with dissent and co-responsibility in social crises.

\section{Modeling of social entrepreneurship}

A model is a proposal for measuring categories, variables and indicators[45]. In this way, entrepreneurship is assumed as a category that includes dimensional variables such as resource optimization and process innovation[46]. Both dimensions continue to be variables such as opportunism, efficiency, environmentalism, resilience or governance[47]. Relationship trajectories are created in a model. In the case of entrepreneurship, two routes prevail: One that goes from opportunism to optimization of resources, ending in resilience[48]. Another that goes from trust to efficiency leading to governance[49]. A third route would go from creativity, through process innovation and culminating in comanagement agreements.

The modeling of the venture in three axes assumes that the parties: a) do not have access to sufficient information to plan and systematize their responses to the health and economic crisis; b) they aspire to a confidence that allows them to optimize and innovate; c) they are aware of the risks posed by their agreements and co-responsibilities; d) correct their informational and strategic definitions with cooperation; e) decide and execute provisional strategies in the face of the pandemic.

\section{Method}

A documentary study was carried out with a selection of sources indexed to international repositories: Academia, Copernicus, Dialnet, Dimensions, Ebsco, Frontiers, Google, Latindex, Microsoft, Redalyc, Scielo, scopus, Zenodo and Zotero, considering the publication period of 2019 to 2021 (see Table 1).

\begin{tabular}{llll}
\multirow{2}{*}{$\begin{array}{l}\text { Table 1. Descriptive sample } \\
\text { Repository }\end{array}$} & \multicolumn{2}{l}{ Entrepreneurship } \\
\hline & 2019 & 2020 & 2021 \\
\hline Academia & 3 & 2 & 4 \\
\hline Copernicus & 2 & 3 & 3 \\
\hline Dialnet & 1 & 1 & 5 \\
\hline Dimensions & 3 & 4 & 4 \\
\hline Ebsco & 2 & 3 & 5 \\
\hline Frontiers & 4 & 2 & 4 \\
\hline Google & 2 & 4 & 3 \\
\hline Latindex & 1 & 3 & 2 \\
\hline Microsoft & 3 & 2 & 4 \\
\hline Redalyc & 2 & 1 & 3 \\
\hline Scielo & 1 & 4 & 5 \\
\hline Scopus & 3 & 3 & 3 \\
\hline Zenodo & 2 & 5 & 2 \\
\hline Zotero & 2 & 4 & 4
\end{tabular}

The Systematic Review Inventory was used, which includes the findings related to the dimensions of the undertaking, considering the selected literature and the established publication threshold[50]. Studies that associated entrepreneurship with other variables were discarded, considering that the review only refers to the dimensions of entrepreneurship (see Table 2).

Table 2. Description of the instrument

\begin{tabular}{llll}
\hline Code & Author & Age & Dimensions \\
\hline d1 & Tapia et al., & 2021 & Opportunism \\
\hline d2 & Stroka \& Meyer & 2021 & Efficacy \\
\hline d3 & Plaza et al., & 2021 & Green \\
\hline d4 & Villa et al., & 2021 & Corporative \\
\hline d5 & Dewanet al., & 2020 & Resiliency \\
\hline
\end{tabular}

The Delphi technique was used[51]. Expert judges in entrepreneurship rated selected findings, considering 1 for the opportunistic dimension, 2 for the resilient dimension, 3 for the green dimension, 4 for the efficient dimension, 5 for the corporate dimension. In the second phase, the grades were compared with the averages to reconsider or reiterate the evaluation. In the third phase, a reconsideration or reiteration of the initial rating was reflected (see Table 3 ). 
Table 3. Descriptive of the judges

\begin{tabular}{lllll}
\hline H index & Sex & Age & Income & Area \\
\hline 23 & Male & 53 & $18^{\prime} 324.00$ & Production \\
\hline 24 & Female & 47 & $19^{\prime} 321.00$ & Logistic \\
\hline 21 & Male & 53 & $1^{\prime} 435.00$ & Quality \\
\hline 26 & Male & 62 & $25^{\prime} 821.00$ & HR \\
\hline 35 & Female & 58 & $45^{\prime} 792.00$ & Production \\
\hline 41 & Female & 55 & $2^{\prime} 324.00$ & Logistic \\
\hline 37 & Female & 41 & $36^{\prime} 781.00$ & Logistic \\
\hline 44 & Male & 67 & $40^{\prime} 321.00$ & HR \\
\hline 56 & Male & 58 & $53^{\prime} 786.00$ & HR \\
\hline 42 & Male & 63 & $6^{\prime} 891.00$ & Quality \\
\hline
\end{tabular}

The data were processed in the package for social sciences version 23 , considering the parameters of normal distribution, linearity and homoscedasticity, previous requirements for the analysis of contingencies, correlations and structures[52]. The estimation of the adjustment and residual coefficients was carried out with the software of structural moments version 4.

\section{Results}

The values of the parameters that measure normality, linearity and homoscedasticity suggest the analysis of contingencies between the category of entrepreneurship with respect to the five dimensions reported in the literature. This means that the relationships between the entrepreneurship category with respect to the dimensions are reflective. This is so because entrepreneurship theory suggests multiple dimensions that are structured as risks intensify. Thus, the literature reports findings that explain the impact of contingent scenarios such as the pandemic on the responses of the parties involved. From this advance, it is possible to analyze the contingent relationships between category and dimensions (see Table 4).

Table 4. Distribution of normality and contingency

\begin{tabular}{ccccccc}
\hline & M & SD & KSL & $\chi 2$ & df & p \\
\hline R1 & \multicolumn{7}{c}{$\mathrm{N}=180$} & & & \\
\hline d1 & 4.63 & 4.52 & 5.32 & 15.21 & 14 & $<.05$ \\
\hline $\mathrm{d} 2$ & 4.52 & 4.65 & 5.31 & 16.21 & 15 & $<.05$ \\
\hline $\mathrm{d} 3$ & 4.87 & 4.70 & 5.40 & 17.10 & 13 & $<.05$ \\
\hline $\mathrm{d} 4$ & 4.92 & 4.62 & 5.47 & 18.51 & 12 & $<.05$ \\
\hline $\mathrm{d} 5$ & 4.72 & 4.17 & 5.32 & 18.21 & 14 & $<.05$ \\
\hline $\mathrm{R} 2$ & \multicolumn{7}{c}{$\mathrm{N}=140$} & & & \\
\hline $\mathrm{d} 1$ & 4.32 & 4.53 & 5.32 & 10.21 & 10 & $>.05$ \\
\hline $\mathrm{d} 2$ & 4.90 & 4.31 & 5.72 & 16.32 & 14 & $>.05$ \\
\hline $\mathrm{d} 3$ & 4.21 & 4.62 & 5.42 & 11.54 & 13 & $>.05$ \\
\hline $\mathrm{d} 4$ & 4.78 & 4.41 & 5.04 & 15.32 & 18 & $>.05$ \\
\hline $\mathrm{d} 5$ & 4.53 & 4.02 & 5.21 & 10.32 & 15 & $>.05$ \\
\hline $\mathrm{R} 3$ & \multicolumn{7}{c}{$\mathrm{N}=160$} & & & \\
\hline
\end{tabular}

\begin{tabular}{lllllll}
\hline d1 & 4.80 & 4.29 & 5.46 & 14.35 & 14 & $>.05$ \\
\hline d2 & 4.62 & 4.37 & 5.94 & 18.32 & 12 & $>.05$ \\
\hline d3 & 4.41 & 4.31 & 5.32 & 19.21 & 14 & $>.05$ \\
\hline d4 & 4.31 & 4.29 & 5.48 & 10.45 & 16 & $>.05$ \\
\hline d5 & 4.52 & 4.21 & 5.21 & 13.24 & 15 & $>.05$ \\
\hline
\end{tabular}

Note: $\mathrm{R}=$ Round, $\mathrm{d}=$ Dimensions, $\mathrm{M}=$ Mean, $\mathrm{SD}=$ Standard Deviation, KSL $=$ Kolmogorov Smirnoff Lilliefords,

Once the normal, linear and contingent distributions were established, the correlations between the dimensions were estimated in order to establish a concomitant structure between the category and the dimensions. Such findings suggest that entrepreneurship is associated with the dimensions reported in the literature, as well as its structure centered on the qualification of expert judges (see Table 5).

Table 5. Correlations between dimensions

\begin{tabular}{llllll}
\hline & $\mathrm{d} 1$ & $\mathrm{~d} 2$ & $\mathrm{~d} 3$ & $\mathrm{~d} 4$ & $\mathrm{~d} 5$ \\
\hline $\mathrm{d} 1$ & 1.0 & $.45^{*}$ & $.53^{*}$ & $.54^{*}$ & $.53^{*}$ \\
\hline $\mathrm{d} 2$ & & 1.0 & $.62^{* *}$ & $.68^{* *}$ & $.38^{*}$ \\
\hline $\mathrm{d} 3$ & & & 1.0 & $.63^{* *}$ & $.65^{*}$ \\
\hline $\mathrm{d} 4$ & & & & 1.0 & $.58^{* * *}$ \\
\hline $\mathrm{d} 5$ & & & & & 1.0 \\
\hline
\end{tabular}

Note: $\mathrm{d} 1=$ Opportunism, $\mathrm{d} 2=$ Efficacy, $\mathrm{d} 3=$ Green, $\mathrm{d} 4=$ Corporative, d5 $=$ Resilience. ${ }^{*} \mathrm{p}<.01 ; * * \mathrm{p}<.001 ; * * * \mathrm{p}$ $<.0001$

The correlations between the dimensions suggested the estimation of a structural equation model (see Figure 1). A structure of axes, trajectories and relationships was found that explain entrepreneurship in risk situations. It means then that entrepreneurship as the axis and central category was associated with its dimensions in situations and risk events such as the pandemic. Thus, the adjustment and residual parameters $\left[x^{2}=14.21(24 \mathrm{df}) \mathrm{p}>.05\right.$; GFI $=.997$; $\mathrm{CFI}=$ .990 ; RMSEA $=.009]$ suggest the non-rejection of the null hypothesis of reflection of entrepreneurship in the five dimensions reported by the literature. 


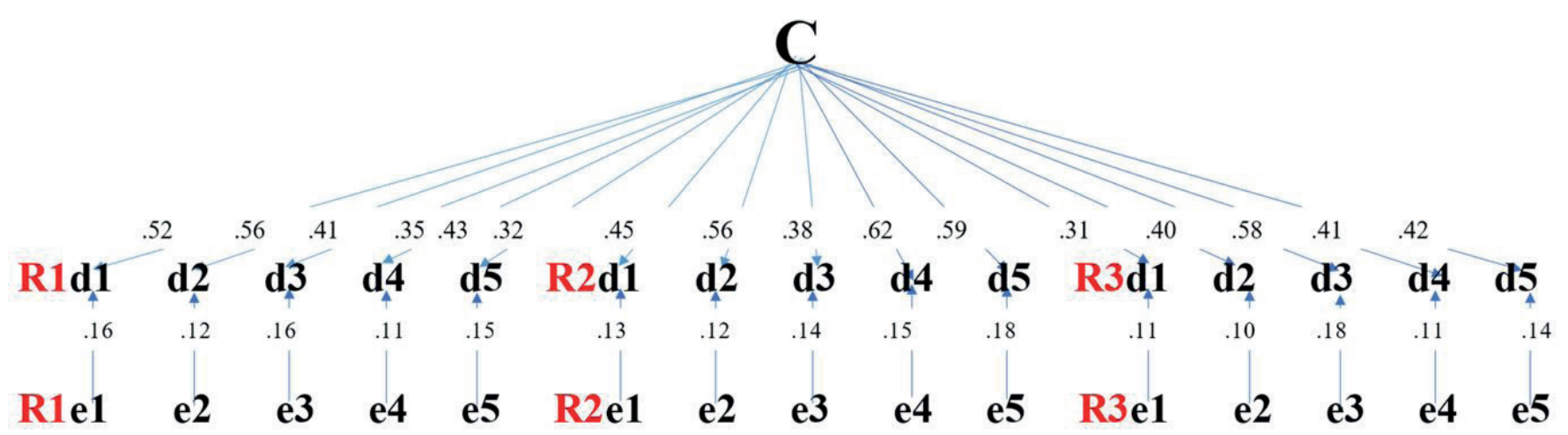

Figure 1. Structural equation modelling

Source: Elaborated with data study. $\mathrm{R}=$ Round, $\mathrm{d}=$ Dimensions, $\mathrm{C}=$ Category, $\mathrm{e}=$ Error measurement

\section{Discussion}

The contribution of this work was the review of entrepreneurship as an emerging phenomenon in the pandemic. The relationship between rulers and ruled in health and economic crisis was consulted in the literature reports published from 2019 to 2021. A structure of five preponderant factors was found that explained the relationship between the parties involved.

In relation to the theory of social entrepreneurship, which explains that government and entrepreneurs aspire to generate trust and agreements, the present work suggests that the literature considers five axes of analysis related to opportunism, efficacy, environmentalism, resilience and governance. It means then that the sources consulted disseminate a multifactorial undertaking in which it is possible to investigate diversified decisions and strategies in the face of risk events.

Regarding the studies of entrepreneurship where the relationships between categories, variables and indicators are not consolidated, the present work corroborates this trend. The established structure suggests that it is possible to analyze relationship trajectories from findings that may be related, but not established as associations that allow explaining the diversification of entrepreneurship.

Regarding the modeling of entrepreneurship where three routes are outlined that go from opportunism, creativity and trust to co-responsibility, resilience and co-management, the present work suggests that such paths can be complementary, although it is also possible that they are exclusive to as the pandemic intensifies. Study lines related to the modeling of the categories, dimensions, variables, factors and indicators will allow anticipating a systematic review. Future investigations concerning the axes of trajectories will predict the diffusion of findings.

\section{Conclusion}

In the Covid-19 era, the mitigation and containment policies of the pandemic were implemented as a restriction to agglomerations, distancing and social confinement. In this scenario, the literature on entrepreneurship reports five dimensions related to opportunism, effectiveness, environmentalism, governance and resilience. In this sense, political and social actors, public and private sectors converge in an entrepreneurial response to the health and economic crisis. The present work corroborated this structure, its dimensions and findings. Lines of study related to the impact of entrepreneurship on community, local or municipal resilience will allow anticipating responses to risk, contingency and crisis scenarios.

\section{References}

[1] A. Alessa, T. M. Alotaibie, Z. Elmoez, H. E. Alhamad. "Impacto of Covid-19 on entrepreneurship and consumer behavior: A case study in sauudi Arabia." Journal of Asian Finance Economic \&amp; Business, Vol. 8 (1), pp. 201-210 2021. Doi: https://dx.doi. org/10.13106/jafeb.2021.vol8.no5.0201

[2] N. Ritwathanavanich, J. Bejawak, S, Pavapanunkul. "Performance of the innovation passion model for post Covid-19 entrepreneurs." Utoia \&amp; Praxis Latinoamericana, Vol. 26(2), pp. 123-137 2021. Doi: https://doi.org/10.5281/zenodo.4678862

[3] N. Caseiro, A. Coelho. "The inflluence of business intelligence capacity networking learning aand innovativeness startups performance." Journal of Innovation \&amp; Knowledge, Vol. 4(1), pp.139-145, 2019. Doi: https://doi.org/10.1016/j.jik.2018.03.009

[4] A. Rodríguez. "Nuevas perspectivas para entender el emprendimiento empresarial". Pensamiento \&amp; gestión,Vol. 26 (1), pp. 94-130, 2009

[5] E, Velázquez, A. E. Urbiola. "Decisiones familiares y teoría de juegos: micro emprendimiento y género". Innovaciones de Negocios, Vol. 18(35), pp. 1-31, 2021 
[6] V. Ratten. "Covid-19 and entrepreneurship: Future research direction." Vol. 30 (1), pp. 91-98, 2021. Doi: https://dx.doi.org/10.1002/jsc.2392

[7] V. Olvecka. "Development of entrepreneurial environment in Slovaquia." Intellectual Economics, Vol.7(1), 2016-229, 2013. Doi: https://dx.doi. org/10.13165/IE-13-7-2-06

[8] G. Dushnitsky. "Entrepreneurial optimism in the market for technological interventions." Organizational Science, Vol. 21(1) pp. 150-167, 2010. Doi: https://dx.doi.org/10.1287/orsc.1090.0454

[9] G. Tejeda, Z. Rubio, M. Berrelleza, M. S. Plazola. "Emprendimiento en los grupos vulnerables." Relayn, Vol. 5(21), pp. 71-92, 2021

[10] J. O. Quevedo. "Impacto del Covid-19 en el emprendimiento del sector turístico en el Ecuador." Dominio de la Ciencia, Vol. 6 (3), pp. 1352-1367, 2020. Doi: http://dx.doi.org/10.23857/dc.v6i3.1377

[11] X. A. Vélez, S. Ortiz. "Emprendimiento e innovación: Una aproximación teórica. Dominio de la Ciencia, Vol. 2(4), pp.346-369, 2016

[12] V. Ratten. "Coronavirus (COVID-19) and entrepreneurship: changing life and work landsplace." Journal of Smmall Business \&amp; Entrepreneurship. Vol. 32(5), pp. 503-516, 2020. Doi: https://doi.org/10. 1080/08276331.2020.1790167

[13] F. J. Ferreiro. "Mujer y emprendimiento. Una especial a los viveros de Galicia." RIPS, Vol. 12 (3), pp. 81101, 2013.

[14] I. Maldonado. "Soluciòn de inteligencia de negocios y toma de decisiones en la gestión administrativa en boticas." Revista Investigación \&amp; Cultura Vol. 3(2), pp.1-8, 2014

[15] M. J. Murillo, G. Cáceres. "Business intelligence y la toma de decisiones financieras una aproximación financiera." Revista Logos, Ciencia \&amp; Tecnología, Vol. 5 (1), pp. 119-138, 2013

[16] J. L. Martinez. "The propensity for entrepreneurship psychological and social factors." Cuadernos de Latinoamericanos de Administración, Vol. 6(10), pp. $51-76,2010$

[17] A. Salamzadeh, D. Kirby. "New venture creation how star ups grow?" AD Miniter, Vol. 30(1), pp. 9-29, 2017

[18] B. Martínez, O. Cote, Z. Dueñas, A. Camacho, "El teletrabajo: Una opción para la extensión de maternidad en Colombia". Revista Derecho, Vol. 48 (1), pp. 1-20, 2017

[19] L. Fuentes lsaz, J. Montero. ¿Qué hace que algunos emprendedores sean más innovadores? Universia Bussiness Review, Vol. 47( 1), pp. 14-31, 2015

[20] D. J. Teece, A. Y. Al-Aali, "Knowledge, entrepreneurship and capabilities.Revising the theory of the MMN." Universia Business Review, Vol. 40 ( 1), pp. 18-32, 2013

[21] D. M. Knight. "Opprtunism and diversification: entre preneurship and livehood strategies and uncertain times". Etnnos, Vol. 80( 1), pp. 117-144, 2015

[22] S. Tuzlukaya, E. Kirkbesoglu, "A theoretoical model for institutional change: the relations between institutional enytrepreneurship and social capital." International of Business \&amp; management, Vol. 10(3), pp. 91-99, 2015

[23] F. J. Fuentes, S. M. Sánchez. "Análisis del perfil emprendedor: Una perspectiva de género". Estudios de Economía Aplicada, Vol. 28( 3), pp. 1-28, 2010

[24] E. Ahumada, J. M. Perrusquia. "Inteligencia de negocios: estrategia para el desarrollo de competitividad en empresas de base tecnológica". Contaduría \&amp; Administración, Vol. 61(1), pp. 127-158, 2016

[25] W. Sroka, N. Meyer. "A theoretical analysis of entreprneurship: the case of Poland and South Africa". Journal of Earten Europe and Centra Asian Research, Vol. 8( 1), pp. 133-149, 2021

[26] M. D. Dewan, K. Nadheem, E. Rayeva, U. Ahmed. "Covid-19 and financial performance oof SME's: Examining the nexus of entrepreneurial self-efficacy, resilience and innovative work behavior." Vol. 29( 3), pp. $587-593,2020$

[27] H. B. Lee, G. S. Katz, A. F. Restori. "A Monte Carlo study of seven homogeneity variance test". Journal of Mathematics \&amp; Statistics, Vol. 6( 3), pp. 359366,2010

[28] J. L. Ventura, T. Caycho. "El coeficiente omega un método alternativo para la estimación de la confiabilidad". Revista Latinoamericana de Ciencias Sociales, Vol. 15(1), pp. 625-627, 2017

[29] Pedrosa, J. Juarros, A. Robles, J. Basteiro, E. Garcia. "Pruebas de bondad de ajuste con distribuciones simétricas". Vol. 14( 1), pp. 15-24, 2015

[30] G. Gjolov. "An equal variance test". Estudios de Economía, Vol. 29(2), pp.327-339, 2002

[31] A. Villa, M. J. Arias, Begoña, M. "Un modelo de formación para desarrollar el emprendimiento social". Educar, Vol. 57( 1) pp. 97-116, 2021

[32] D. Plaza, C. M. Banegas, Y. Castillo. "Los emprendimientos verdes una alternativa de sostenibilidad para las pymes en la Ciudad de la Cuenca.”. Visión Digital. Vol. 5(2), pp. 6-29, 2021

[33] M. P. llanos. "Otras formas de desempeño laboral: Emprendimiento autónomo en estudiantes de la universidad tecnológica ECOTEC". Ecociencia, Vol. 6(4), pp. 1-17, 2019

[34] E. Tapia, J. Rivera, J. Sancjez. "Análisis de 
factores migratorios, laborales y psicosociales en el emprendimiento de migrantes retornados en la mixteca poblana, México." Revista de Economía, Vol. 36( 96), pp. 71-88, 2021

[35] A. Velázquez Orozco, L. García Espinoza, M. Zainos Hernández, y C. García Lirios, "Specification of a local entrepreneurship model", SINFRONTERA, (33), pp. 1-16, dic. 2020

[36] C. García Lirios, C. Y. Quiroz Campas, G. Bermúdez Ruíz, F. R. Sandoval Vázquez, y O. I. Carreón Valencia, "Reliability and Validity of an Instrument that Measures Entrepreneurship", PG, vol. 49, nov. 2020

[37] C. García Lirios, J. Carreón Guillén, y J. A. Aguilar Fuentes, "Activismo ante el establecimiento de la agenda", Realidades, vol. 4(2), pp.127-159, mar. 2017

[38] T. J..Hernández-Gracia, J.C. . Guillén, and C. . GarcíaLirios, "Reengineering in the Entrepreneurship of the Coffee Industry and Tourism in Central Mexico", AM, vol. 9(2), pp. 63-81, Apr. 2021

[39] C. García Lirios, J. Carreón Guillén, J. M. Bustos Aguayo, y J. Hernández Valdés, "Percepción del emprendimiento caficultor en la región Huasteca, centro de México", Rev. act., vol. 18(1), pp. 235-266, sep. 2020

[40] E. Martínez Muñoz, "Hybrid determinant model of the coffee entrepreneurship", IS(8), nov. 2019

[41] J. Bustos Aguayo, C. García Lirios, y M. Juárez Nájera, "Validity of a habitus model of coffee entrepreneurship", SUMMA, vol.3(1), pp. 1-21, ene. 2021

[42] A. Sánchez-Sánchez, J. M. Bustos Aguayo, J. Hernández Vádés, J. Carreón Guillén, E. Martínez Muñoz, y C. García Lirios, "Estructura factorial de los determinantes del acoso organizacional", cuad. hispanoam.psicol, vol. 18(1), feb. 2020

[43] C. García Lirios, "GESTIÓN DEL CONOCIMIENTO, ACTIVOS INTANGIBLES Y CAPITALES INTELECTUALES EN LA ERA DE COVID-19”, RIMCI, vol. 16(8), pp.13-26, jul. 2021

[44] J. Carreón Guillén, J. Hernández Valdés, y C. García Lirios, "Prueba empírica de un modelo de establecimiento de agenda", Acta Universitaria, vol. 24(3), pp. 50-62, jul. 2014

[45] C. García Lirios, "Modelo de expectativas en torno a la seguridad pública en microempresarios del centro de México", Dixi, vol. 20(28), pp. 1- 13, ene. 2019

[46] C. García Lirios, J. Carreón Guillén, y J. Hernández Valdés, "Gobernanza de Desarrollo Humano: Contrastación de un modelo de los determinantes perceptuales de la intención de uso de Internet en usuarios de una biblioteca pública de la Ciudad de México., IS, (3), pp. 39-56, jul. 2017
[47] A. Sánchez Sánchez, J. Carreón Guillén, H. D. Molina Ruíz, y C. García Lirios, "Contratación de un Modelo de Formación Laboral”, IS,(5), pp. 37-73, ago. 2018

[48] C. García Lirios, "Escenario Hídrico en la Ciudad de México: Revisión 2019-2021”., RGE, vol. 11(21), pp. 48-63, jul. 2021

[49] C. García Lirios, "Metaanálisis dimensional de la confianza: implicaciones para la comunicación social de la covid-19", CITAS, vol. 6(1), dic. 2020

[50] J. M. Bustos Aguayo, M. Juárez Nájera, F. R. Sandoval Vázquez, M. L. Quintero Soto, y C. García Lirios, "Percepciones sobre la calidad y las tarifas del servicio de agua potable de los usuarios de Ciudad de México", Revista Educación y Desarrollo Social, vol. 11 (2), pp. 20-31, ene. 2018

[51] F. R. Sandoval-Vázquez, J. M. Bustos Aguayo, y C. García-Lirios, "Desarrollo Local en la Era Post Covid-19”, ESH, vol. 9 (18), pp. 17-22, jul. 2021 